\title{
Ontogenetic dietary changes in male South American fur seals Arctocephalus australis in Patagonia
}

\author{
Damián G. Vales ${ }^{1, *}$, Luis Cardona ${ }^{2}$, Néstor A. García ${ }^{1}$, Lisette Zenteno², \\ Enrique A. Crespo ${ }^{1}$
}

\begin{abstract}
${ }^{1}$ Laboratory of Marine Mammals, Centro Nacional Patagónico (CENPAT),
Consejo Nacional de Investigaciones Científicas y Técnicas (CONICET), Blvd. Brown 2915, Puerto Madryn 9120, Argentina

${ }^{2}$ IRBio and Department of Animal Biology, Faculty of Biology, University of Barcelona, Av. Diagonal 643, Barcelona 08028, Spain
\end{abstract}

\begin{abstract}
This study assessed ontogenetic dietary changes in male South American fur seals Arctocephalus australis in northern and central Patagonia (Argentina) using stable isotope ratios $\left(\delta^{15} \mathrm{~N}\right.$ and $\left.\delta^{13} \mathrm{C}\right)$ in vibrissae and bones. Sucking pups were characterised by higher $\delta^{15} \mathrm{~N}$ values and lower $\delta^{13} \mathrm{C}$ values than older specimens. Weaning was associated with a marked drop of $\delta^{15} \mathrm{~N}$ values, both in bone and vibrissae. Such a drop was inconsistent with the consumption of local prey and may reveal movement to distant foraging grounds or physiological changes associated with either fasting or rapid growth. Stable isotope ratios indicated that juveniles fed more pelagically than subadults and adults, but that there were no major differences between the 2 latter age categories. As subadults and adults are rather similar in body mass and are much larger than juveniles, body mass may play a role in the ontogenetic dietary changes reported. Nevertheless, demersal benthic prey were always scarce in the diet of male fur seals, which relied primarily on Argentine shortfin squid and small pelagic fish throughout life, though adults also consumed large amounts of decapod crustaceans available at shallow depths. Vibrissae did not reveal regular oscillations of $\delta^{15} \mathrm{~N}$ or $\delta^{13} \mathrm{C}$, except in 1 individual. Thus, male fur seals from northern and central Patagonia do not appear to migrate regularly between isotopically distinct areas, although nomadic displacements cannot be ruled out.
\end{abstract}

KEY WORDS: Foraging ecology · Pinniped - Arctocephalus australis · Ontogenetic dietary change · Stable isotope analysis $\cdot \delta^{15} \mathrm{~N} \cdot \delta^{13} \mathrm{C} \cdot$ Patagonia

\section{INTRODUCTION}

Many marine mammals undergo clear differences in foraging behaviour during their life as a result of changes in their physiology, foraging skill, energy requirements at different stages, or differences in experience when a learning period is required for the successful use of a particular foraging tactic (Heithaus \& Dill 2008). In eared seals, the capacity to exploit demersal prey is linked to body size, as it is a major determinant of the ability to dive deeper and longer, and to handle large prey (Costa et al. 2004, Drago et al. 2009a, Weise et al. 2010). As a conse- quence, opportunistic foragers may increase the consumption of benthic prey as they grow (Drago et al. 2009a, Weise et al. 2010), although such ontogenetic dietary change does not always occur and some species forage epipelagically throughout their life (Orr et al. 2011). Most fur seals in the genus Arctocephalus indeed are pelagic foragers (Majluf 1989, Acuña \& Francis 1995, Reid et al. 2006, Aurioles-Gamboa \& Camacho-Ríos 2007, Franco-Trecu et al. 2012, Páez Rosas et al. 2012, Makhado et al. 2013, Franco-Trecu et al. 2014, Lalas \& Webster 2014), probably because their small body size limits oxygen stores and hence reduces time underwater and the chance of captur- 
ing demersal prey (Gentry et al. 1986, Kooyman 1989, Costa 1991, Costa et al. 2004). The exceptions are the 2 fur seal subspecies with the largest body size within the genus: A. pusillus pusillus and A. $p$. doriferus (Arnould 2008), which exploit prey mainly associated with the bottom (Stewardson 2001, Page et al. 2005). In addition, the foraging habitat can also be a key component of the foraging behaviour. For instance, benthic prey remain outside the scope of seal species that forage beyond the continental shelf (Lewis et al. 2006, Hückstädt et al. 2007).

The South American fur seal Arctocephalus australis (Zimmermann, 1783) breeds from Uruguay to Peru (Vaz-Ferreira 1982). In the south-western Atlantic Ocean, the species forages both on the continental shelf and beyond (Pinedo 1986, 1998, Thompson et al. 2003, Laptikhovsky 2009, Dassis et al. 2012), and relies primarily on small pelagic fishes, squids and invertebrates (Strange 1983, 1992, Naya et al. 2002, Oliveira et al. 2008, Franco-Trecu et al. 2012, Baylis et al. 2014, Vales et al. 2014). However, nothing has been published from Patagonia, where ca. 20000 ind. congregate on a few islands (Svendsen et al. 2013, Crespo et al. 2015) to take advantage of the high marine productivity of the region (Acha et al. 2004, Rivas et al. 2006, Lutz et al. 2010). Furthermore, the San Matías Gulf in northern Patagonia has been proposed as a potential foraging area during the post-breeding season for South American fur seals moving between Uruguayan and Patagonian breeding colonies (Svendsen et al. 2013). Regarding dietary ontogeny of this species, information is scarce but indicates a nursing period that lasts between 8 and 12 mo (Vaz-Ferreira \& Ponce de León 1984, 1987), where pups do not incorporate solid foods, and nutritional needs are fully covered by maternal milk (Ponce de León 1984). After an abrupt weaning, the first phase of nutritional independence is characterised by early predation on squid and fish (Gerpe et al. 2009). For this species, ontogenetic dietary changes in subsequent age classes have not been investigated, but the use of neritic habitats suggests that consumption of demersal prey may increase with age and body size (Drago et al. 2009a, Weise et al. 2010).

Combining traditional dietary methods (i.e. stomach content or scat analyses) with stable nitrogen and carbon isotope $\left(\delta^{15} \mathrm{~N}\right.$ and $\left.\delta^{13} \mathrm{C}\right)$ analysis provides improved resolution in the interpretation of trophic interactions (Post 2002). Whereas the former allow a precise taxonomic description of the prey consumed (Hobson \& Wassenaar 1999), the latter can reveal summarised trophic information over a broader time and space window (Martin et al. 2011). Stable nitrogen-15 and carbon-13 isotope analysis is based on a predictable relation between the isotopic composition of a consumer and its prey (DeNiro \& Epstein $1978,1981)$. For aquatic organisms, $\delta^{15} \mathrm{~N}$ values can provide data on trophic level (Minagawa \& Wada 1984, Post 2002) and feeding area (Chouvelon et al. 2012) while $\delta^{13} \mathrm{C}$ values can reveal information on feeding locations, including the relative use of benthic vs. pelagic and coastal vs. oceanic prey (Hobson et al. 1994, France 1995). This general pattern was found to be true for the northern Patagonia marine ecosystem, where benthic prey are more enriched in both ${ }^{15} \mathrm{~N}$ and ${ }^{13} \mathrm{C}$ than pelagic ones (Forero et al. 2004, Drago et al. 2009a,b). Further, this approach has proved to be a reliable tool for evaluating ontogenetic dietary shifts in many eared seals species (Hobson \& Sease 1998, Newsome et al. 2006, Drago et al. 2009a, Orr et al. 2011, Kernaléguen et al. 2012). Thus, some of the most important events in the life of mammals (e.g. nursing, weaning and feeding) are reflected in the isotopic composition of its tissues. For instance, during lactation $\delta^{15} \mathrm{~N}$ values increase because mothers catabolise their body tissues to synthesise milk, placing sucking pups one trophic level higher than lactating females; at the same time, $\delta^{13} \mathrm{C}$ values decrease because pinniped milk is extremely rich in ${ }^{13} \mathrm{C}$-depleted lipids compared to the piscivorous diet of weaned animals (Hobson \& Sease 1998, Newsome et al. 2006). In turn, weaning was identified in vibrissae of subantarctic fur seals Arctocephalus tropicalis and southern elephant seals Mirounga leonina as a sudden drop in $\delta^{15} \mathrm{~N}$ values (Kernaléguen et al. 2012, Walters et al. 2014).

This study aims to evaluate the ontogenetic dietary changes in South American fur seals in northern and central Patagonia through stable isotope analysis. However, because female fur seals are infrequently found stranded in the study area, the present study is focused only on males. Two different approaches were used: (1) a population-level (cross-sectional) approach using bone tissue of individuals of different age categories; and (2) an individual-level (longitudinal) approach using vibrissae that were serially sampled all along their length from yearling, juvenile, subadult and adult fur seals. Further, comparison of the isotopic values of bones and vibrissae can potentially reveal dietary information over multiple temporal scales. Bone collagen is a slow turnover tissue which in marine mammals is expected to integrate stable isotope ratios over several years (Riofrío-Lazo \& Aurioles-Gamboa 2013) and acts as a long-term integrator of isotopic fluctuations (Schoeninger \& De- 
Niro 1984, Lee-Thorp et al. 1989, Hirons et al. 2001a). On the other hand, otariid vibrissae are synthesised rapidly from the proximal end inside the bulb. Since keratin is metabolically inert and is not resorbed following synthesis, the biochemical composition of vibrissae reflects the diet at the time of their growth (Hobson 1999, Cherel et al. 2009); besides, otariid vibrissae grow continuously at a constant rate and are not shed (Hirons et al. 2001b). Therefore, by comparing the isotopic values along the length of vibrissa with those of potential prey, shifts in resources and foraging habitat can be interpreted for the temporal span depicted by the growth of the vibrissa (Hirons et al. 2001b). In brief, while the use of stable isotope ratios in bone samples is an adequate method to assess potential dietary changes of a predator at a population level over long timescales (Schoeninger \& DeNiro 1984, Lee-Thorp et al. 1989, Hirons et al. 2001a), vibrissae allow the reconstruction of the trophic history of an individual with a monthly resolution for several consecutive years (Hirons et al. 2001b, Cherel et al. 2009, Kernaléguen et al. 2012).

\section{MATERIALS AND METHODS}

\section{Sampling}

Sixty-one skulls of male South American fur seals found dead and stranded along the Atlantic coast of northern and central Patagonia (approximately bounded by $41^{\circ}$ and $46^{\circ} \mathrm{S}$ ) from 1980 to 2013 , were sampled from the collection of the Centro Nacional Patagónico (Puerto Madryn, Argentina). In order not to damage the skulls, a small fragment of maxilloturbinal bone from the nasal cavity was used for isotopic analysis (Drago et al. 2009b). Bone samples were stored dry until analysis. In addition, 9 dead stranded individuals of male South American fur seals (2 yearlings, 2 juveniles, 1 subadult and 4 adults) were collected from 2007 to 2011, in northern and central Patagonia. From each individual, the largest vibrissa was chosen and extracted from its root (Stegall et al. 2008). Tissue debris coming from the vibrissae follicle were removed with a scalpel blade (Lewis et al. 2006). Vibrissae were handwashed with running water, dried at room temperature and stored dry until analysis.

Potential prey of South American fur seals were identified from stomach content (Crespo et al. 2008) and scats $(n=487)$ collected on central Patagonia (Arce and Rasa islands) during the period 1999 to 2009 (E. A. Crespo unpubl. data). According to these surveys, the most important prey were Argentine shortfin squid Illex argentinus, Argentine anchovy Engraulis anchoita, Argentine hake Merluccius hubbsi and Patagonian squid Loligo gahi. Secondary prey were banded cusk-eel Raneya brasiliensis, Argentine red shrimp Pleoticus muelleri, lobster krill Munida gregaria morph subrugosa and Notothenioid rockcods Patagonotothen spp., among others. Accordingly, these prey species were sampled from January 2006 to April 2010 from this region for isotopic analysis. White dorsal muscle was sampled for fish, muscle for shrimp, and mantle for squid; whereas in the case of lobster krill due to its small size the whole body was sampled. All samples were stored in a freezer at $-20^{\circ} \mathrm{C}$ until analysis. Some of these isotopic values for potential prey targeted by South American fur seals have already been published in a previous work (Drago et al. 2009a,b). No living animals were manipulated during this study, as fur seals were found dead on beaches and prey samples were obtained from fishery discards.

\section{Age determination}

Individual ages were estimated from counts of growth layer groups (GLGs; Scheffer 1950) in the dentine and/or in the cementum of teeth. Three different techniques were used for age determination: direct counting of external rings on canine root, thin ground sections of undecalcified teeth, and decalcified and stained thin sections made with a freezing microtome. The technique employed depended on the availability of teeth from each individual (canines, incisors or post-canines) and it was assumed that one GLG is deposited per year (Schiavini et al. 1992, Crespo et al. 1994, Molina-Schiller \& Pinedo 2004). Teeth were read 3 times by at least 2 readers. Subsequent readings by the same reader were spaced by at least $1 \mathrm{wk}$. When readings were coincidental, that age was assigned to the individual. Whenever counting differed by less than $10 \%$ of the average of the 3 reads, the mean of the readings was taken as the age of the specimen (Calzada et al. 1994). Where counts exceeded this arbitrary limit, teeth were re-examined or another tooth was prepared.

Once the age was determined, individuals were categorised as yearling (from 1 to $1.9 \mathrm{yr}$ ), juvenile (from 2 to $4.9 \mathrm{yr}$ ), subadult (from 5 to $7.9 \mathrm{yr}$ ) and adult (from 8 to $19 \mathrm{yr}$ ) based on literature (Vaz-Ferreira \& Ponce de León 1984, Batallés et al. 1990, Borella et al. 2013). 


\section{Stable isotope analysis}

Maxillo-turbinal bone and prey samples were dried in a stove at $60^{\circ} \mathrm{C}$ for 36 to $48 \mathrm{~h}$ and ground to a fine powder with a mortar and pestle. Lipids were extracted with a chloroform/methanol (2:1) solution (Bligh \& Dyer 1959). Since bone samples contain a high concentration of inorganic carbon that may add undesirable variability to $\delta^{13} \mathrm{C}$ (Lorrain et al. 2003), they were treated by soaking for $24 \mathrm{~h}$ in $0.5 \mathrm{~N}$ hydrochloric acid $(\mathrm{HCl})$ to decarbonise them (Newsome et al. 2006). Given that $\mathrm{HCl}$ treatment may affect $\delta^{15} \mathrm{~N}$ (Bunn et al. 1995), each sample was divided into 2 subsamples: one was used for ${ }^{13} \mathrm{C}$ analysis after decarbonising and the other one was used for ${ }^{15} \mathrm{~N}$ analysis without decarbonising.

Vibrissae were washed in a chloroform/methanol (2:1) solution and cleaned in distilled water for $5 \mathrm{~min}$ in an ultrasonic bath to eliminate any surface contaminants (Newsome et al. 2010a). The entire vibrissae, from the newest part synthesised within the vibrissae follicle to the tip, were measured, dried in a stove at $60^{\circ} \mathrm{C}$ for $36 \mathrm{~h}$ and cut into $3 \mathrm{~mm}$ long consecutive sections starting from the proximal end (Cherel et al. 2009).

Approximately $1 \mathrm{mg}$ of dried bone, $0.30 \mathrm{mg}$ of prey tissues, and an average weight of $0.35 \mathrm{mg}$ of the entire length of each $3 \mathrm{~mm}$ vibrissa section were weighed into tin cups. Weighed samples were combusted at $900^{\circ} \mathrm{C}$, and analysed in a continuous flow isotope ratio mass spectrometer. Most samples were analysed at the Centres Científic i Tecnològics of the University of Barcelona (CCiT-UB), where international isotope secondary standards given by the International Atomic Energy Agency (IAEA) were used for calibration at a precision of $0.3 \%$ for nitrogen and $0.2 \%$ for carbon. However, a few bone samples were analysed at the Instituto de Geocronología y Geología Isotópica (INGEIS-CONICET/UBA), where international isotope secondary standards given by IAEA were used for calibration at a precision of $0.2 \%$ for both nitrogen and carbon. Hence, to test for possible biases between these 2 laboratories, 5 bone samples were analysed in both. Stable isotope abundance is expressed in standard $\delta$ notation relative to carbonate Pee Dee Belemnite and atmospheric nitrogen. Carbon to nitrogen (C:N) mass ratio was used as proxy for data quality (e.g. adequate lipid extraction; Newsome et al. 2010b).

\section{Data analysis}

Before performing any statistical tests, the adequacy of their assumptions were verified by means of a modified Shapiro-Wilks test for normality and by checking plots of standardised residual vs. fitted values for homoscedasticity.

\section{Bones}

Bone samples were collected during the past 4 decades (1980-2013). To discard any temporal trend that may interfere with the interpretation of the ontogenetic series, the relationship between isotopic values $\left(\delta^{15} \mathrm{~N}\right.$ and $\left.\delta^{13} \mathrm{C}\right)$ and the stranding year was tested for the age categories best represented in the sample (i.e. subadult and adult male fur seals) by Pearson correlation analysis.

Except for yearling male fur seals, which are expected to be influenced by the persistence of the sucking signal (Newsome et al. 2006), the relationship between isotopic values $\left(\delta^{15} \mathrm{~N}\right.$ and $\left.\delta^{13} \mathrm{C}\right)$ and age was investigated for individuals of older age categories by Spearman rank correlation analysis.

The relative contributions of potential prey to the diet of subadult and adult male fur seals were calculated using the Bayesian mixing model SIAR (Stable Isotope Analysis in $R_{;}$Parnell et al. 2008). Through application of trophic discrimination factors (TDFs) to consumer isotopic values, the isotopic composition of fur seal tissues were compared directly to those of its diet. Stable isotope values of prey and those of fur seals corrected by the corresponding TDFs were plotted previously to the selection of the potential prey to run mixing models (Phillips et al. 2014). Estimated TDFs from diet to bone reported for adult males of the species were used $\left(\delta^{15} \mathrm{~N}=+5.1 \%\right.$; $\delta^{13} \mathrm{C}=$ $+3.6 \%$; Vales et al. 2014). Maximum errors measured from the internal laboratory standards $\left(0.3\right.$ for $\delta^{15} \mathrm{~N}$ and 0.2 for $\delta^{13} \mathrm{C}$ ) were used to set the uncertainty (standard deviation) of the TDFs. Juveniles were excluded from the mixing model analysis due to the uncertainty in the TDFs, which is expected to change between fast growing (e.g. juvenile) and non-growing (e.g. adult) animals (Martínez del Rio et al. 2009).

\section{Vibrissae}

Fur seal vibrissae isotopic values were compared to those of main prey. Since no TDFs from diet to vibrissa are available for South American fur seals, correction was made by averaging $\delta^{15} \mathrm{~N}$ and $\delta^{13} \mathrm{C}$ diet vibrissa TDFs experimentally determined for captive seals and sea otters (Hobson et al. 1996, Newsome et al. 2010a), thus resulting in the averaged TDFs from diet to vibrissa of $+3.15 \pm 0.5 \%$ or $\delta^{15} \mathrm{~N}$ and $+2.7 \pm$ $0.7 \%$ for $\delta^{13} \mathrm{C}$ used in this study. Mixing model SIAR 
were run to estimate the relative contribution of potential prey to the diet of subadult and adult male fur seals.

It is known that some eared seals species show consistent annual isotopic oscillations $\left(\delta^{15} \mathrm{~N}\right.$ and $\left.\delta^{13} \mathrm{C}\right)$ along the length of their vibrissae, revealing changes in prey items and/or foraging areas (Hirons et al. 2001b, Cherel et al. 2009, Kernaléguen et al. 2012). Thus, to explore any periodicity in the isotopic oscillations of vibrissa in subadult and adult male South American fur seals, the Ïnon-parametric spectral method Fourier analysis and autocorrelation functions were used; cross-correlation analysis was used to test whether $\delta^{15} \mathrm{~N}$ and $\delta^{13} \mathrm{C}$ oscillated synchronously. Vibrissae of yearling and juvenile individuals were excluded from these analyses, since they are likely to be influenced by the sucking signal and weaning (Kernaléguen et al. 2012).

\section{RESULTS}

\section{Bones}

Stable isotope values of fur seal bone from the 2 laboratories did not differ significantly (Paired Wilcoxon test, $\delta^{15} \mathrm{~N}$ : mean difference $=-0.15, \mathrm{p}=0.109$; $\delta^{13} \mathrm{C}$ : mean difference $=0.27, \mathrm{p}=0.507 ; \mathrm{N}=5$ ). Further, no temporal trend was found in the last 3 de-

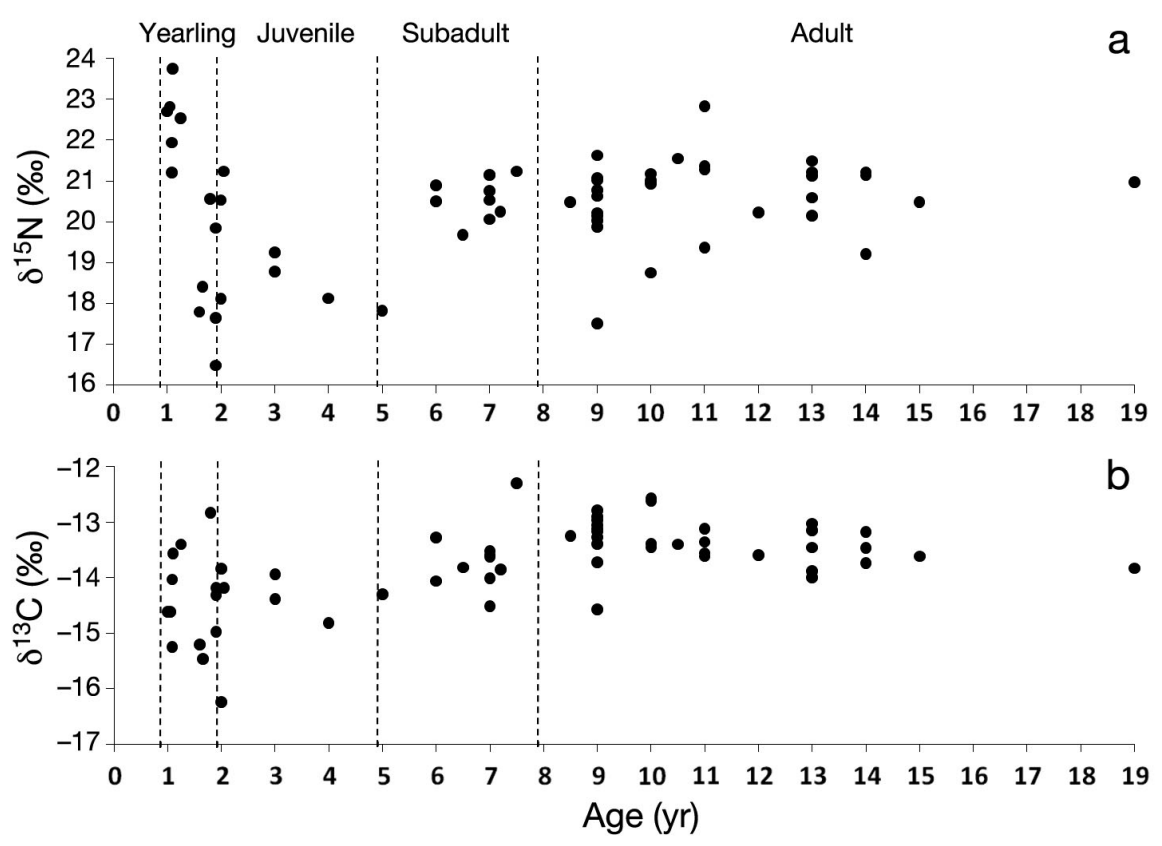

Fig. 1. Stable isotope values of (a) $\delta^{15} \mathrm{~N}$ and (b) $\delta^{13} \mathrm{C}$ of skull bones of male Arctocephalus australis $(\mathrm{n}=61)$ divided by age categories cades between fur seals older than 5 yr (subadult and adults) and the stranding year (Pearson correlation; $\delta^{15} \mathrm{~N}: \mathrm{r}=0.02, \mathrm{p}=0.886 ; \delta^{13} \mathrm{C}: \mathrm{r}=-0.05, \mathrm{p}=0.762 ; \mathrm{N}$ $=43$ ). Thus, bone samples were pooled and considered suitable for exploring potential ontogenetic dietary changes.

The $\delta^{15} \mathrm{~N}$ and $\delta^{13} \mathrm{C}$ values of skull bone ranged from +16.5 to $+23.8 \%$ (mean $=+20.4 \%$, SD $=1.4)$ and from -16.2 to $-12.3 \%$ o (mean $=-13.7 \%$, $\mathrm{SD}=0.7)$, respectively. Carbon to nitrogen (C:N) mass ratio ranged from 2.7 to $3.1($ mean $=2.8, \mathrm{SD}=0.1$; Table 1$)$. The stable isotope values of skull bone of each individual are shown in Fig. 1. The $\delta^{15} \mathrm{~N}$ values of yearlings were extremely variable due to the isotopic signature of tissues from the youngest individuals. When yearlings where excluded from the analysis, both $\delta^{15} \mathrm{~N}$ and $\delta^{13} \mathrm{C}$ increased significantly with age (Spearman rank correlation; $\delta^{15} \mathrm{~N}$ : rs $=0.36, \mathrm{p}=0.01 ; \delta^{13} \mathrm{C}: \mathrm{rs}=0.37, \mathrm{p}=$ $0.01 ; \mathrm{N}=49$ ). However, considering the low correlation coefficients and the similarity between the isotopic values of subadult and adult fur seals (Table 1), the main change in diet seem to occur between juvenile and subadult fur seals.

When subadult and adult males were plotted in the isotopic landscape of northern and central Patagonia, after correcting the $\delta^{15} \mathrm{~N}$ and $\delta^{13} \mathrm{C}$ values for diet-to-bone discrimination, they were located well within a polygon formed by Argentine shortfin squid, anchovy, Patagonian squid, juvenile hakes, red shrimp and lobster krill (Fig. 2). Conversely, benthic fish remained outside the isotopic niche exploited by all age categories of fur seals. Regarding juvenile fur 


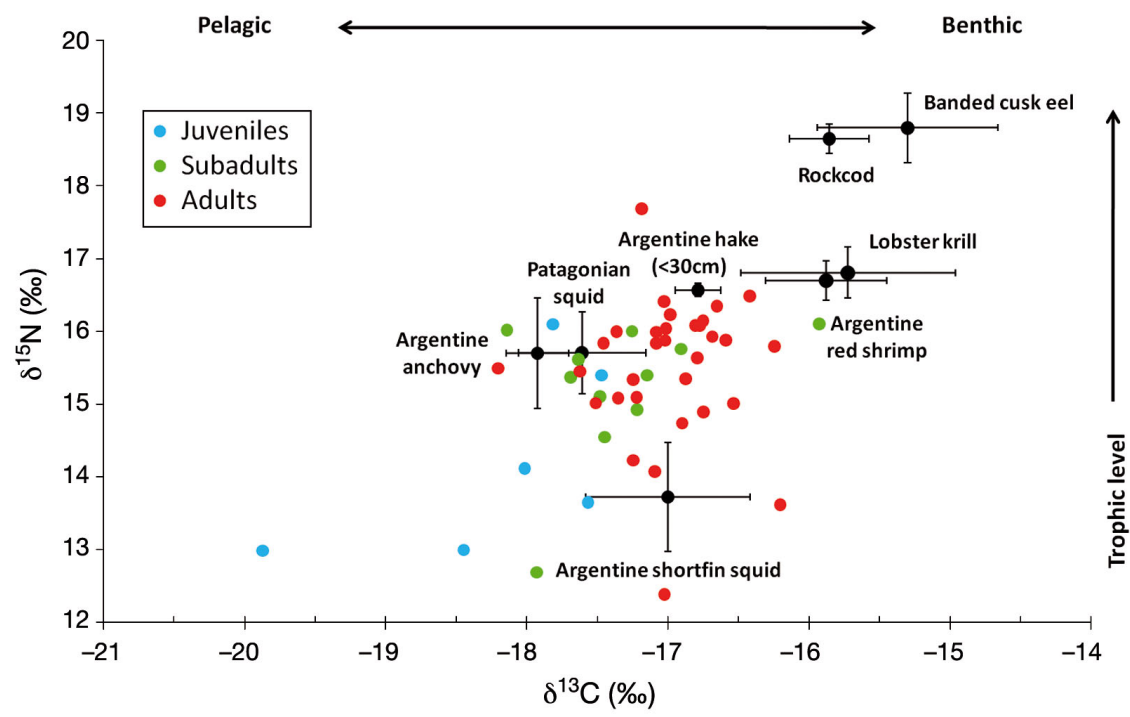

Fig. 2. Isotopic landscape of the main prey (black dots, mean; whiskers, SD) of male Arctocephalus australis and the stable isotope values $\left(\delta^{15} \mathrm{~N}\right.$ and $\left.\delta^{13} \mathrm{C}\right)$ of bone samples from juvenile, subadult and adult male fur seals after the corresponding trophic discrimination factors were applied seals, most of them lay outside the mixing polygon, thus revealing the consumption of unsampled prey, or alternatively the TDF estimated for adult fur seals is not well-suited for this age class. Prey other than benthic fishes were used to run the SIAR model, though red shrimp and lobster krill were grouped as decapod crustaceans, due to their similar isotopic signal and taxonomic affinity (see Table 2). Mixing models revealed that the anchovy and the 2 species of squid contributed almost evenly to the diet of subadult individuals. For their part, adult male fur seals had a more even diet, with Argentine shortfin squid standings as the major prey and a higher consumption of crustaceans (Fig. 3).

Table 2. Stable isotope values of $\delta^{13} \mathrm{C}, \delta^{15} \mathrm{~N}$ and the C:N mass ratio (mean $\pm \mathrm{SD}$ ) of the potential prey of Arctocephalus australis. Sample size (n); ecological groups: small pelagic fish (SPF), demersal benthic fish (DBF), demersal pelagic cephalopod (DPC), and demersal benthic and benthic crustacean ( $\mathrm{DBCr}$ and $\mathrm{BCr}$, respectively)

\begin{tabular}{|c|c|c|c|c|c|c|}
\hline Species & Common name & $\begin{array}{l}\text { Ecological } \\
\text { group }\end{array}$ & $\mathrm{n}$ & $\delta^{13} \mathrm{C}(\%)$ & $\delta^{15} \mathrm{~N}(\%)$ & $\begin{array}{c}\mathrm{C}: \mathrm{N} \text { mass } \\
\text { ratio }\end{array}$ \\
\hline Engraulis anchoita $^{\mathrm{a}}$ & Argentine anchovy & SPF & 5 & $-17.9 \pm 0.2$ & $15.7 \pm 0.8$ & $3.1 \pm 0.0$ \\
\hline Merluccius hubbsi $(<30 \mathrm{~cm})$ & Argentine hake & SPF & 4 & $-16.8 \pm 0.2$ & $16.6 \pm 0.1$ & $3.1 \pm 0.0$ \\
\hline Raneya brasiliensis ${ }^{\mathrm{a}}$ & Banded cusk eel & $\mathrm{DBF}$ & 5 & $-15.3 \pm 0.6$ & $18.8 \pm 0.5$ & $3.0 \pm 0.0$ \\
\hline Patagonotothen spp. & Notothenioid rockcods & $\mathrm{DBF}$ & 4 & $-15.9 \pm 0.3$ & $18.6 \pm 0.2$ & $3.1 \pm 0.1$ \\
\hline Illex argentinus ${ }^{\mathrm{a}}$ & Argentine shortfin squid & $\mathrm{DPC}$ & 5 & $-17.0 \pm 0.6$ & $13.7 \pm 0.8$ & $3.0 \pm 0.0$ \\
\hline Loligo gahi $^{\mathrm{a}}$ & Patagonian squid & $\mathrm{DPC}$ & 4 & $-17.6 \pm 0.4$ & $15.7 \pm 0.6$ & $3.0 \pm 0.0$ \\
\hline Pleoticus muelleri & Argentine red shrimp & $\mathrm{DBCr}$ & 5 & $-15.9 \pm 0.4$ & $16.7 \pm 0.3$ & $2.9 \pm 0.0$ \\
\hline Munida gregaria morph subrugosa & Lobster krill & $\mathrm{BCr}$ & 5 & $-15.7 \pm 0.8$ & $16.8 \pm 0.3$ & $3.3 \pm 0.1$ \\
\hline
\end{tabular}
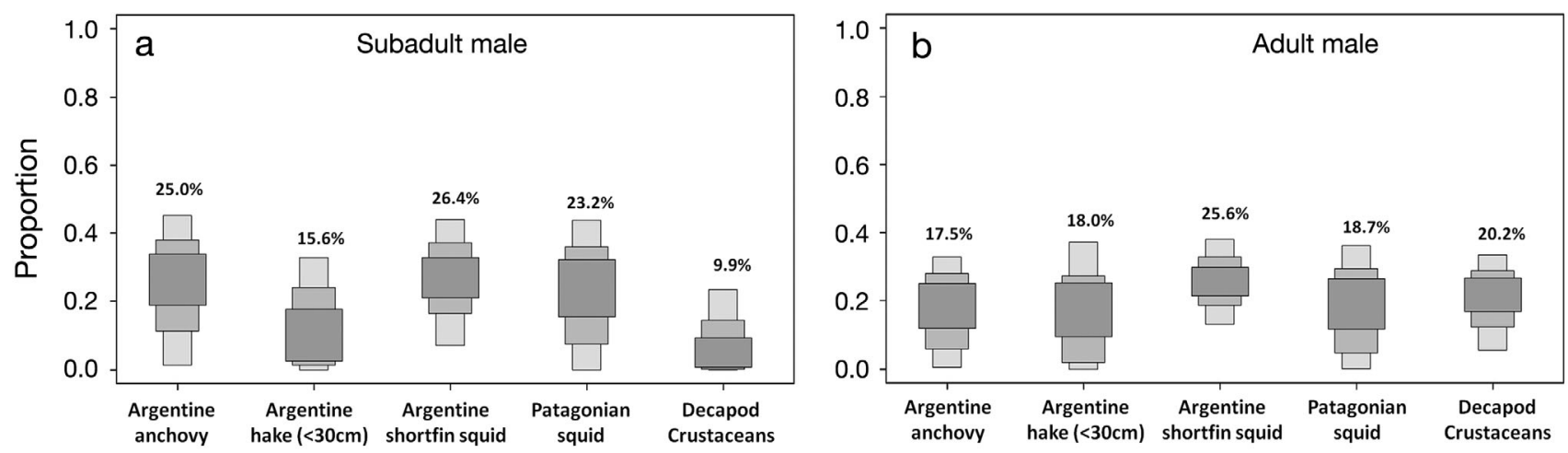

Fig. 3. Bayesian mixing model SIAR (Stable Isotope Analysis in R) analysis outcome based on bone samples showing the estimated contribution of prey in the diet of (a) subadult and (b) adult male Arctocephalus australis. The mean contribution of each prey is shown above each box-plot. Median 50\%, 75\% and 95\% credibility intervals (respectively dark grey, mid grey and light grey boxes) of the posterior probability distributions of proportions in diet are shown 
Table 3. Stable isotope values of $\delta^{13} \mathrm{C}, \delta^{15} \mathrm{~N}$ and the $\mathrm{C}: \mathrm{N}$ mass ratio (mean $\pm \mathrm{SD}$ ) of vibrissae of yearling, juvenile, subadult and adult male Arctocephalus australis

\begin{tabular}{|lccccccc|}
\hline $\begin{array}{l}\text { Sample Category } \\
\text { ID }\end{array}$ & $\begin{array}{c}\text { Age } \\
\text { (yr) }\end{array}$ & $\begin{array}{c}\text { Vibrissa } \\
\text { length } \\
(\mathrm{mm})\end{array}$ & $\begin{array}{c}\text { No. of } \\
\text { vibrissa } \\
\text { sections }\end{array}$ & $\delta^{13} \mathrm{C}(\%)$ & $\delta^{15} \mathrm{~N}(\%)$ & $\begin{array}{c}\text { C:N mass } \\
\text { ratio }\end{array}$ \\
\hline Aa69 & Yearling & 1.9 & 123 & 41 & $-15.4 \pm 0.7$ & $18.5 \pm 1.8$ & $2.9 \pm 0.0$ \\
Aa70 & Yearling & 1.9 & 72 & 24 & $-15.8 \pm 0.7$ & $17.8 \pm 2.1$ & $2.9 \pm 0.0$ \\
Aa71 & Juvenile & 3 & 93 & 31 & $-15.5 \pm 0.7$ & $17.0 \pm 2.8$ & $2.9 \pm 0.1$ \\
Aa72 & Juvenile & 3 & 120 & 40 & $-15.2 \pm 0.7$ & $17.0 \pm 0.6$ & $2.9 \pm 0.0$ \\
Aa84 & Subadult & 7 & 141 & 47 & $-14.4 \pm 0.4$ & $18.7 \pm 0.5$ & $2.9 \pm 0.0$ \\
Aa58 & Adult & 13 & 108 & 36 & $-14.7 \pm 0.3$ & $18.4 \pm 0.6$ & $2.9 \pm 0.0$ \\
Aa81 & Adult & 13 & 129 & 43 & $-13.8 \pm 0.4$ & $18.6 \pm 0.7$ & $2.9 \pm 0.1$ \\
Aa85 & Adult & 13 & 132 & 44 & $-14.1 \pm 0.2$ & $18.9 \pm 0.6$ & $3.0 \pm 0.0$ \\
Aa86 & Adult & 11 & 108 & 36 & $-14.2 \pm 0.6$ & $18.3 \pm 0.7$ & $2.9 \pm 0.0$ \\
\hline
\end{tabular}

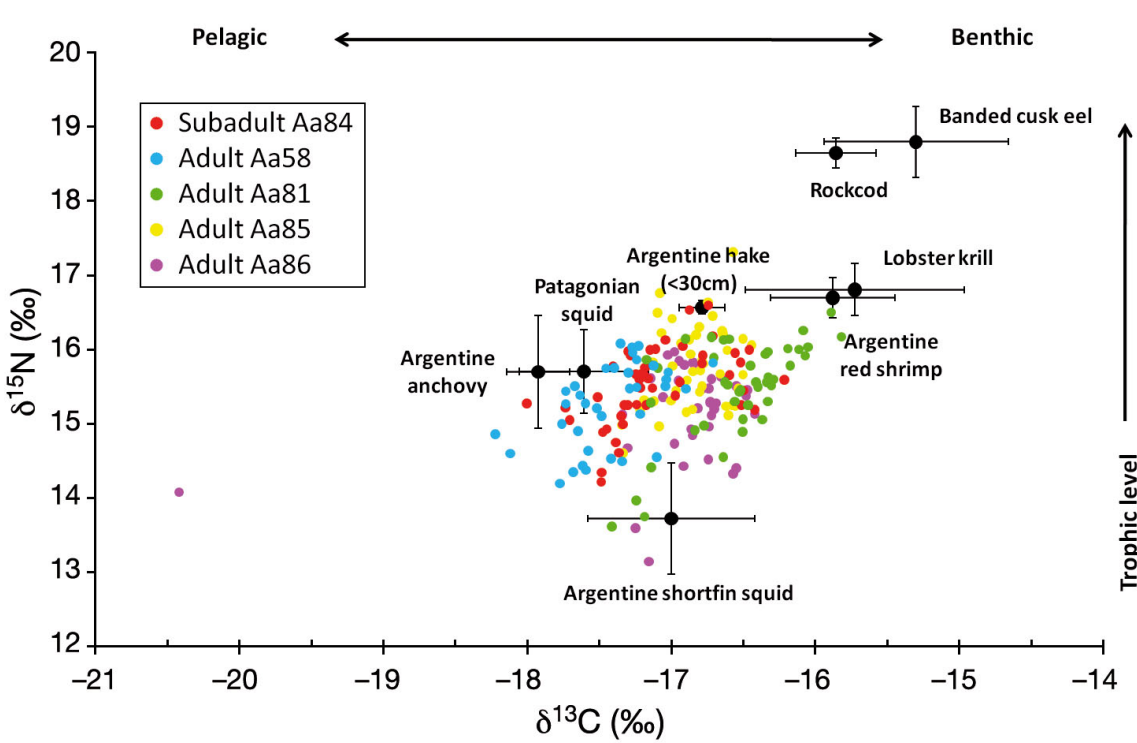

Fig. 4. Isotopic landscape of the main prey (black dots, mean; whiskers, SD) of male Arctocephalus australis and stable isotope values $\left(\delta^{15} \mathrm{~N}\right.$ and $\left.\delta^{13} \mathrm{C}\right)$ of vibrissa samples (3 mm long consecutive sections) from 1 subadult and 4 adult males after the corresponding trophic discrimination factors were applied

\section{Vibrissae}

A total of 338 sections of vibrissae of South American fur seals were analysed. The length of vibrissae varied from 72 to $141 \mathrm{~mm}$ (24 to 47 sections, respectively). Nitrogen and carbon stable isotope values of vibrissae ranged from +12.3 to $+20.6 \%$ (mean $=$ $+18.1 \%$, SD = 1.4) and from -17.7 to $-13.1 \%$ o $($ mean $=-14.8 \%$, $\mathrm{SD}=$ $0.8)$, respectively. Four missing data values and 3 cases where the $C: N$ mass ratio was higher than the expected values from pure keratin (Newsome et al. 2010b) were replaced by averaged values interpolated from adjacent points. Mean carbon to nitrogen $(\mathrm{C}: \mathrm{N})$ mass ratio ranged from 2.9 to 3.0 (Table 3). After correcting fur seal isotope values to those of its potential prey through diet to vibrissae TDFs, subadult and adult fur seals lay within a polygon conformed by Argentine shortfin squid, anchovy, Patagonian squid, juvenile hakes, red shrimp and lobster krill; whereas benthic fish showed little contribution to the diet of fur seals. In one case a vibrissa section was extremely ${ }^{13} \mathrm{C}$-depleted, escaping from the landscape (Aa86; Fig. 4). Mixing models
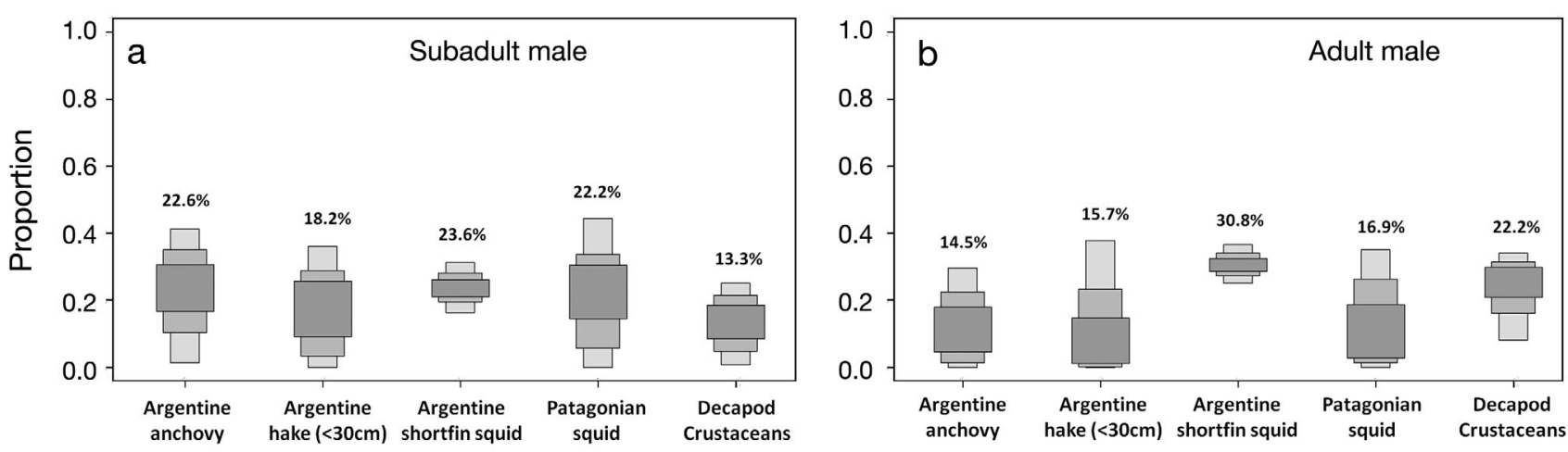

Fig. 5. Bayesian mixing model SIAR (Stable Isotope Analysis in R) analysis outcome based on vibrissa samples showing the estimated contribution of prey in the diet of (a) 1 subadult and (b) 4 adult male Arctocephalus australis. The mean contribution of each prey is shown above each box-plot. Median $50 \%, 75 \%$ and $95 \%$ credibility intervals (respectively dark grey, light grey and white boxes) of the posterior probability distributions of proportions in diet are shown 
based on the isotopic values of vibrissae revealed that this subadult fur seal (Aa84) had almost equal contributions in its diet of small pelagic fishes and squids, and a relatively low contribution of crustaceans. The diet of adult fur seals showed a great contribution of Argentine shortfin squid and an increased consumption of crustaceans (Fig. 5).
The 2 yearlings (Aa69, Aa70) and 1 juvenile (Aa71) showed similar $\delta^{15} \mathrm{~N}$ and $\delta^{13} \mathrm{C}$ oscillation patterns along their vibrissae. While $\delta^{15} \mathrm{~N}$ exhibited high values at a very early age, followed by a sudden drop and recuperation up to the range of diet isotopic values; $\delta^{13} \mathrm{C}$ mirrored this pattern, but showed low values at a very early age (Fig. 6a). The simultaneous
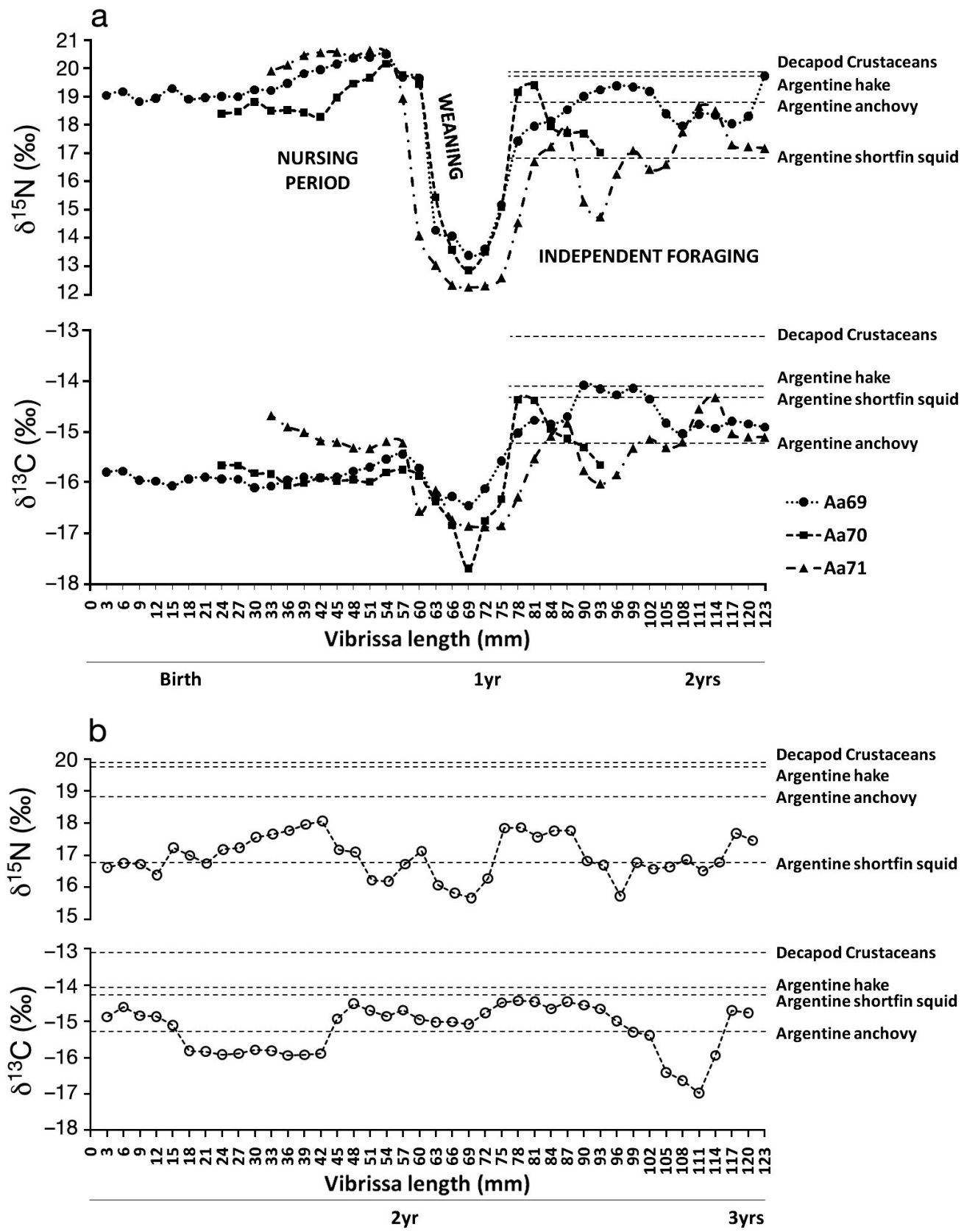

Fig. 6. Stable isotope values of $\delta^{15} \mathrm{~N}$ and $\delta^{13} \mathrm{C}$ along the vibrissae of 2 yearling and 2 juvenile male Arctocephalus australis. Vibrissae are represented from tip (the oldest part of the vibrissa on the left) to base (the newest part of the vibrissa on the right). Isotopic corrected values $\left(\delta^{15} \mathrm{~N}\right.$ and $\left.\delta^{13} \mathrm{C}\right)$ of fur seals' main prey are showed with a horizontal dotted line. For a better understanding of the time integrated by vibrissae, ages prior to the age of death are roughly indicated for each individual at the bottom of each figure. (a) Overlapped isotopic values from 3 fur seals displaying a similar pattern (Aa69, Aa70 and Aa71). See 'Discussion' for an interpretation of nursing period, weaning and independent foraging. (b) Isotopic values from fur seal Aa72 
Table 4. Autocorrelation and cross-correlation analyses to evaluate periodicity and synchronicity in vibrissa $\delta^{15} \mathrm{~N}$ and $\delta^{13} \mathrm{C}$ values of 1 subadult and 4 adult male Arctocephalus australis. ${ }^{*} \mathrm{p}<0.05$

\begin{tabular}{|c|c|c|c|c|c|}
\hline $\begin{array}{l}\text { Sample } \\
\text { ID }\end{array}$ & $\begin{array}{l}\text { Iso- } \\
\text { topic } \\
\text { ratios }\end{array}$ & $\begin{array}{l}\text { Perio- } \\
\text { dicity } \\
\text { (no. of } \\
\text { sections) }\end{array}$ & $\begin{array}{c}\text { Auto- } \\
\text { correlation } \\
\text { coefficient }\end{array}$ & $\begin{array}{c}\text { Lag between } \\
\delta^{15} \mathrm{~N} \text { and } \delta^{13} \mathrm{C} \\
\text { values (no. } \\
\text { of sections) }\end{array}$ & $\begin{array}{c}\text { Cross- } \\
\text { auto- } \\
\text { correlation } \\
\text { coefficient }\end{array}$ \\
\hline \multirow[t]{7}{*}{ Aa 84} & $\delta^{15} \mathrm{~N}$ & 1 & $0.660^{*}$ & \multirow{7}{*}{$\begin{array}{r}-1 \\
0 \\
1 \\
9\end{array}$} & \multirow{7}{*}{$\begin{array}{r}0.36^{*} \\
0.48^{*} \\
0.39^{*} \\
-0.40^{*}\end{array}$} \\
\hline & & 2 & $0.370^{*}$ & & \\
\hline & & 16 & $0.244^{*}$ & & \\
\hline & & 31 & $0.220^{*}$ & & \\
\hline & \multirow{3}{*}{$\delta^{13} \mathrm{C}$} & 32 & $0.180^{*}$ & & \\
\hline & & 1 & $0.718^{*}$ & & \\
\hline & & 2 & $0.417^{*}$ & & \\
\hline \multirow[t]{5}{*}{ Aa 58} & \multirow[t]{3}{*}{$\delta^{15} \mathrm{~N}$} & 1 & $0.351^{*}$ & \multirow{5}{*}{0} & \multirow{5}{*}{$0.52^{*}$} \\
\hline & & 7 & $0.351^{*}$ & & \\
\hline & & 14 & $0.442^{*}$ & & \\
\hline & \multirow[t]{2}{*}{$\delta^{13} \mathrm{C}$} & 1 & $0.528^{*}$ & & \\
\hline & & 2 & $0.341^{*}$ & & \\
\hline \multirow[t]{4}{*}{ Aa 81} & $\delta^{15} \mathrm{~N}$ & 16 & $0.400^{*}$ & \multirow{4}{*}{$\begin{array}{l}0 \\
1\end{array}$} & \multirow{4}{*}{$\begin{array}{l}0.64^{*} \\
0.47^{*}\end{array}$} \\
\hline & \multirow[t]{3}{*}{$\delta^{13} \mathrm{C}$} & 1 & $0.645^{*}$ & & \\
\hline & & 2 & $0.362^{*}$ & & \\
\hline & & 16 & $0.238^{*}$ & & \\
\hline \multirow[t]{5}{*}{ Aa 85} & \multirow[t]{3}{*}{$\delta^{15} \mathrm{~N}$} & 1 & $0.454^{*}$ & \multirow{5}{*}{$\begin{array}{l}3 \\
4 \\
8\end{array}$} & \multirow{3}{*}{$\begin{array}{l}-0.38^{*} \\
-0.40^{*}\end{array}$} \\
\hline & & 10 & 0.264 & & \\
\hline & & 11 & $0.272^{*}$ & & \\
\hline & \multirow[t]{2}{*}{$\delta^{13} \mathrm{C}$} & 1 & $0.416^{*}$ & & \multirow[t]{2}{*}{$0.43^{*}$} \\
\hline & & 10 & $0.364^{*}$ & & \\
\hline \multirow[t]{3}{*}{ Aa 86} & $\delta^{15} \mathrm{~N}$ & 1 & $0.397^{*}$ & \multirow{3}{*}{-} & \multirow{3}{*}{-} \\
\hline & & 27 & 0.202 & & \\
\hline & $\delta^{13} \mathrm{C}$ & - & - & & \\
\hline
\end{tabular}

drop in $\delta^{15} \mathrm{~N}$ and $\delta^{13} \mathrm{C}$ does not fit with the consumption of prey reported here. On the other hand, another juvenile fur seal (Aa72) displayed a different pattern of isotopic oscillation along the length of its vibrissa (Fig. 6b). For subadult and adult males, Fourier analysis and autocorrelation functions revealed that in a few cases there were consistent periodic fluctuations for both $\delta^{15} \mathrm{~N}$ and $\delta^{13} \mathrm{C}$ values (Aa81 and Aa85), whereas synchronic oscillations between $\delta^{15} \mathrm{~N}$ and $\delta^{13} \mathrm{C}$ were detected in 3 of 5 cases (Aa58, Aa81 and Aa84). However, only 1 adult male (Aa81) showed both periodic fluctuations (every 16 sections) and synchronicity in its isotopic oscillations (Table 4). For this individual, vibrissa recorded 2.7 oscillations; assuming an annual periodicity (see 'Discussion') it is possible to estimate a growth rate for the vibrissa of $0.13 \mathrm{~mm} \mathrm{~d}^{-1}$, wherein each $3 \mathrm{~mm}$ section integrated the isotopic signal of $22.8 \mathrm{~d}$. Nevertheless, all subadult and adult individuals ranged mostly within the range of isotopic values of the main prey (Fig. 7).

\section{DISCUSSION}

The isotopic landscape of the marine ecosystem of northern Patagonia has been described by Drago et al. $(2009 a, b)$ and indicates that potential pelagic prey (e.g. anchovy and squid) are depleted in both ${ }^{15} \mathrm{~N}$ and ${ }^{13} \mathrm{C}$ as compared with potential benthic prey (e.g. banded cusk eel). The potential prey species included in this study followed the same pattern, with pelagic feeders (e.g. juvenile hake) highly depleted in ${ }^{15} \mathrm{~N}$ and ${ }^{13} \mathrm{C}$ as compared with benthic ones (e.g. rockcod). Decapod crustaceans (red shrimp and lobster krill) forage benthically in the region (Vinuesa \& Varisco 2007, Roux et al. 2009) and are also ${ }^{13} \mathrm{C}$ and ${ }^{15} \mathrm{~N}$-enriched as compared with pelagic small schooling fishes and squids, but highly ${ }^{15} \mathrm{~N}$-depleted when compared with demersal fishes. Therefore, variations in $\delta^{15} \mathrm{~N}$ and $\delta^{13} \mathrm{C}$ values of bone and vibrissa after weaning are expected to mainly reflect shifts along the benthic-pelagic gradient (Forero et al. 2004, Drago et al. 2009a,b), whereas changes in trophic level are obscured by the general higher $\delta^{15} \mathrm{~N}$ values of demersal prey as compared with pelagic ones.

Bone and vibrissa samples from South American fur seals revealed a similar pattern, as the collagen synthesised by yearlings, and the keratin synthesised in the proximal end of the vibrissa of yearlings and one juvenile, were always ${ }^{15} \mathrm{~N}$-enriched and ${ }^{13} \mathrm{C}$-depleted as compared with those from older age classes. Such enrichment in ${ }^{15} \mathrm{~N}$ and depletion in ${ }^{13} \mathrm{C}$ has been previously reported in other pinnipeds (Hobson \& Sease 1998, Newsome et al. 2006, Drago et al. 2009a, Orr et al. 2011, Kernaléguen et al. 2012, Walters et al. 2014) and is caused by stable isotope discrimination from the female to the pup during nursing (Newsome et al. 2006). The sucking signal may persist some time after weaning in bone tissue due to a low turnover rate (Newsome et al. 2006, Drago et al. 2009a). A 10 to 12 mo period was estimated for a complete turnover of the sucking signal in the bone collagen of California sea lions Zalophus californianus after weaning (Newsome et al. 2006). If this were the case for South American fur seals (both species have similar nursing periods; Vaz-Ferreira \& Ponce de León 1984, 1987, Newsome et al. 2006), the sucking signal should last in bone up to an age of approx. 18 to $24 \mathrm{mo}$, with fur 

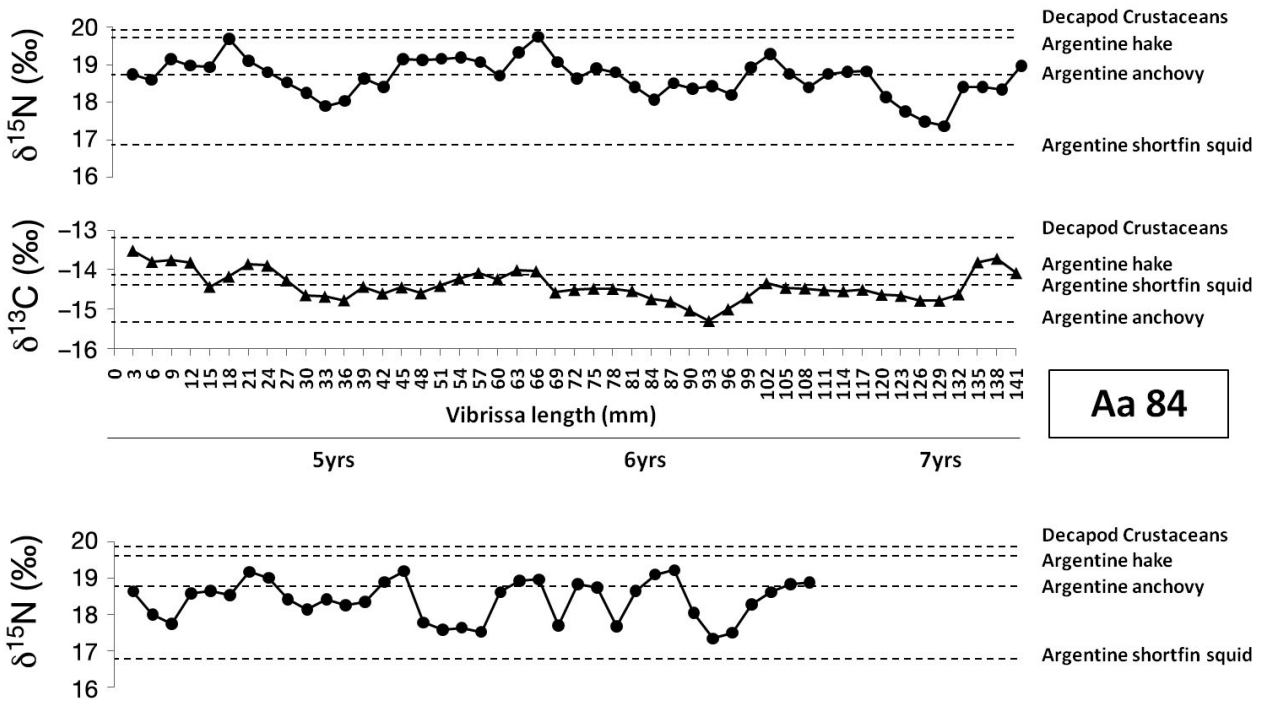

Decapod Crustaceans

Argentine hake Argentine anchovy

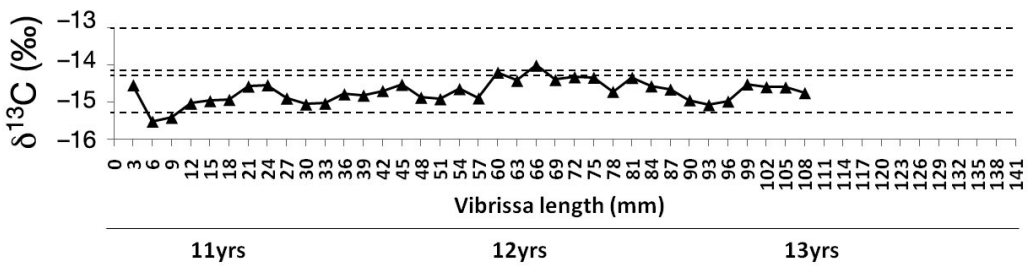

Argentine shortfin squid

Decapod Crustaceans

Argentine hake

Argentine shortfin squid

Argentine anchovy

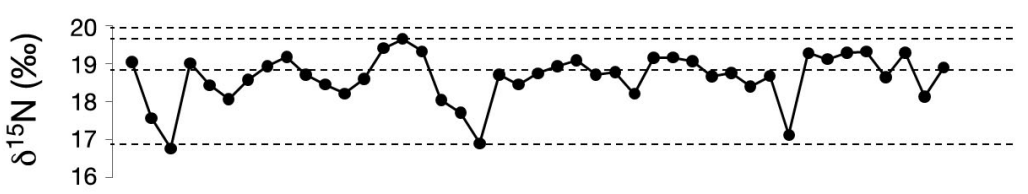

Decapod Crustaceans

Argentine hake

Argentine anchovy

Argentine shortfin squid

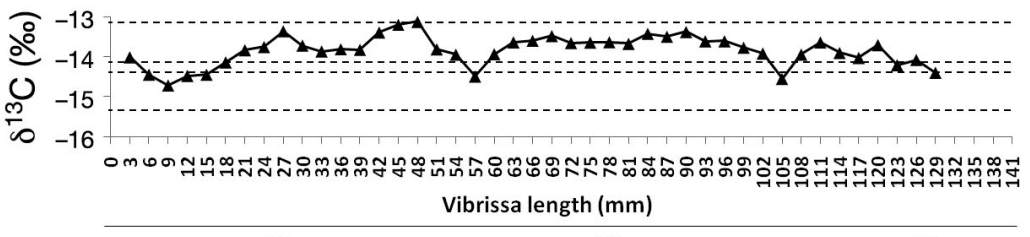

Decapod Crustaceans

Argentine hake

Argentine shortfin squid

Argentine anchovy

$11 \mathrm{yrs}$

12yrs

$13 y r s$

Aa 81

Fig. 7. Stable isotope values of $\delta^{15} \mathrm{~N}$ and $\delta^{13} \mathrm{C}$ along the vibrissa length of 1 subadult and 4 adult male South American fur seals Arctocephalus australis from northern and central Patagonia. Vibrissae are represented from tip (the oldest part) on the left to base (the newest part) on the right. Corrected isotopic values $\left(\delta^{15} \mathrm{~N}\right.$ and $\left.\delta^{13} \mathrm{C}\right)$ of main prey are shown by a horizontal dotted line. For a better understanding of the integrated time by vibrissae, ages prior to the age of death were roughly indicated for each individual at the bottom of each figure

seals older than 2 yr showing exclusively the isotopic signal of independent foraging. However, some fur seals around 2 yr old had relatively high $\delta^{15} \mathrm{~N}$ values, suggesting a longer nursing period or a low bone turnover for this species. In any case, the bone and vibrissa proteins synthesised by most juveniles were depleted in both ${ }^{15} \mathrm{~N}$ and in ${ }^{13} \mathrm{C}$ as compared with those from subadult and adult males. Most likely juvenile fur seals feed on squid and fish (Gerpe et al. 2009), and the inconsistency between bone isotopic values of juveniles and the consumption of local prey reported here is likely to be caused by the lack of an adequate trophic discrimination factor for juveniles, which is expected to change between fast-growing and non-growing animals (Martínez del Rio et al. 2009).

Previous research had already revealed a sudden drop in the $\delta^{15} \mathrm{~N}$ values following weaning in vibrissae of some pinniped species (Kernaléguen et al. 2012, Walters et al. 2014). In turn, a sharp accumulation of heavy metals (mainly cadmium and mercury) from sucking to weaned pups in South American fur seals suggested a rapid transition from lactation to predation on squid and fish (Gerpe et al. 2009). 

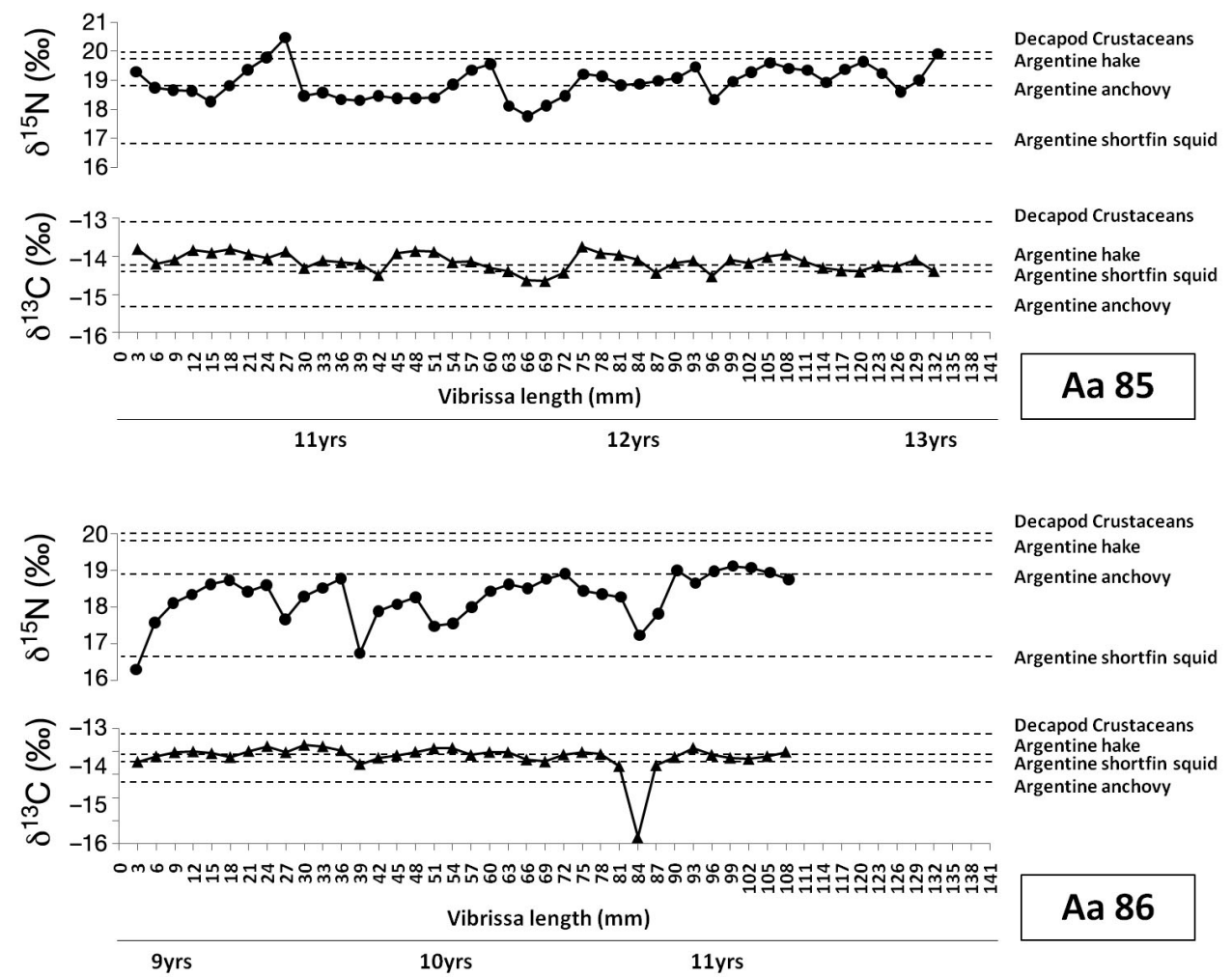

Fig. 7 (continued)

Except for one juvenile, the results reported here are consistent with a sudden dietary change at weaning, indicating an abrupt shift from milk to a solid diet. However, the stable isotope ratios of vibrissae synthesised immediately after weaning are inconsistent with the consumption of local prey, as they are too low. In this sense, Aguilar et al. (2014) have suggested that fasting in marine mammals deprived from access to freshwater is associated with a decrease in the $\delta^{15} \mathrm{~N}$ values of proteins. In addition, different trophic discrimination factors may apply for fast-growing animals (Martínez del Rio et al. 2009). On the other hand, the sharp drop of the $\delta^{15} \mathrm{~N}$ recorded in the tissues of fur seals after weaning might reveal migration to distant foraging grounds. On the whole, the decrease of $\delta^{15} \mathrm{~N}$ values associated with weaning is likely to be affected by a combination of multiple factors and further research is needed to clarify the reason for such a drop.

In any case, stable isotope values in bone and vibrissa suggested an age-related shift in diet after weaning, with juvenile fur seals feeding on more pelagic and possibly lower trophic level prey than subsequent age categories. In turn, subadult and adult males, similar in body size, did not differ in diet, suggesting that body mass plays some role in the ontogenetic dietary changes of fur seals, probably allowing larger individuals to feed on pelagic prey of larger size.

The SIAR model for both bone and vibrissa samples indicated that the Argentine shortfin squid is the most relevant prey for subadult and adult male fur seals, as this species not only had the highest mean feasible contribution to the diet in all cases, but also the credibility interval excluded the probability of no contribution to the diet. Conversely, the credibility intervals of other prey included a zero contribution, thus indicating there is a chance that some of the other potential prey species were not actually consumed. For subadult and adult male fur seals, the contribution of Argentine shortfin squid and juvenile hake was very similar. In contrast, the relevance exhibited by the anchovy and the Patagonian squid was slightly higher in the diet of subadults versus adults, whereas the consumption of decapod crustaceans was slightly higher in adults compared to subadults. However, the contribution of Patagonian squid to fur seal diet may be overestimated by the model, as it has a quite similar isotopic signal to that of the anchovy and the occurrence of Patagonian squid beaks in scats is rather low (E. A. Crespo unpubl. data). If this is the case, the anchovy would have a larger contribution to the diet than that shown by the present model. Conversely, the model attrib- 
utes a greater importance to decapod crustaceans in the diet than observed in scat analysis (E. A. Crespo unpubl. data). In this sense, minor differences observed between the isotopic results, and studies based on scats and stomach contents, may be attributable to the biases inherent in each methodology (see Vales et al. 2014). In addition, it is relevant to consider spatio-temporal variations in isotopic signatures of sampled prey. For instance, isotopic values of juvenile hakes $(<30 \mathrm{~cm})$ collected for this study in April 2010 at a latitude of $45^{\circ} \mathrm{S}$ varied greatly compared to those of juvenile hakes collected in February 2006 at a latitude of $47^{\circ} 10^{\prime} \mathrm{S}$ by Drago et al. (2009a). As isotopic values of prey from both studies (i.e. Drago et al. 2009a and this study) were used to reconstruct the isotopic landscape of the marine ecosystem from northern and central Patagonia, such differences in the isotopic values of any prey should affect the SIAR analysis.

In any case, for northern and central Patagonia, evidence from stable isotope analysis of bone and vibrissa samples (this study) is coincident with the results obtained in stomach contents and scat analyses (Crespo et al. 2008, E. A. Crespo unpubl. data), indicating that Argentine shortfin squid, anchovy and hake are the most relevant prey in the diet of fur seals, with a marginal contribution of benthic fish. Similarly, the dietary importance of small pelagic fish and squid was already recognised for Uruguayan fur seals inhabiting the Río de la Plata and adjoining areas (Naya et al. 2002, Franco-Trecu et al. 2012, Vales et al. 2014). On the other hand, isotopic results from the present study pointed out to decapod crustaceans as prey with some relevance in the diet. Both red shrimp and lobster krill are available at shallow depths (Boschi et al. 1992) and they are the most abundant species in the bottoms of San Jorge Gulf (Vinuesa 2005), adjacent to the fur seal rookeries from Rasa and Arce islands. Despite the fact that lobster krill has a lower energy density than red shrimp, pelagic fish and squid (Ciancio et al. 2007), its small size, its considerable composition of proteins and lipids, and its ability to form large agglomerations, turn it into a preferred prey for many predators (Vinuesa \& Varisco 2007 and references therein), including South American fur seals, as described off the Falkland (Malvinas) Islands (Strange 1983, 1992) and southern Chile (Rodríguez \& Bahamonde 1986; Vallejos 2010 quoted in Seguel et al. 2013).

These observations reinforce the idea that South American fur seals are trophic generalists (Naya et al. 2002), but capture primarily pelagic prey. In the case of male fur seals from northern and central
Patagonia, pelagic squid and small pelagic fishes constitute the bulk of the diet, but decapod crustaceans may also contribute to adult fur seal diet. In contrast to other species of eared seals, in which consumption of benthic prey increases with age as a consequence of improved diving skills (Drago et al. 2009a, Weise et al. 2010) or juveniles rapidly attain the skills needed to consume adult prey types (Orr et al. 2011), South American fur seals remain as pelagic foragers throughout life and the diet of juveniles is different from that of subadults and adults.

Some eared seal species show consistent isotopic oscillations $\left(\delta^{15} \mathrm{~N}\right.$ and $\left.\delta^{13} \mathrm{C}\right)$ along the length of the vibrissae and are interpreted as annual movements between isotopically distinct foraging areas (Hirons et al. 2001b, Cherel et al. 2009, Kernaléguen et al. 2012). However, only one adult male South American fur seal showed consistent periodic oscillations and synchronicity in the $\delta^{15} \mathrm{~N}$ and $\delta^{13} \mathrm{C}$ values of its vibrissa. Periodicity (every 16 sections) is well within the range reported for adult male Antarctic fur seals Arctocephalus gazella breeding at Crozet Islands (from 13 to 20 sections), interpreted as an annual pattern (Cherel et al. 2009). Consequently, given that the same methodology was employed in both studies (i.e. $3 \mathrm{~mm}$ vibrissa sections) and the taxonomic similarity of these species, it is reliable to assume an annual periodicity in the isotopic values of this South American fur seal vibrissa. Furthermore, the growth rate of the vibrissa of this individual $\left(0.13 \mathrm{~mm} \mathrm{~d}^{-1}\right)$ is also similar to that found in male subantarctic fur seals $\left(0.13 \pm 0.02 \mathrm{~mm} \mathrm{~d}^{-1}\right.$; Cherel et al. 2009). Nevertheless, beyond this individual, vibrissae oscillation patterns in the remaining subadult and adult fur seals were more variable, in some cases with no periodicity and/or synchronicity in the $\delta^{15} \mathrm{~N}$ and $\delta^{13} \mathrm{C}$ values.

The isotopic values of vibrissae from all subadult and adult fur seals analysed in this study ranged well within the isotopic values of potential prey from northern and central Patagonia. In addition, the coincidence of $\delta^{15} \mathrm{~N}$ and $\delta^{13} \mathrm{C}$ values in tissues that span different periods (e.g. vibrissae and bones) can be interpreted as a local use of food resources throughout the year without movement of fur seals to other foraging areas. Therefore, vibrissae isotopic oscillations may represent changes in prey consumption at the same area (i.e. northern and central Patagonia) instead of migrations to elsewhere; perhaps responding to changes in prey availability (Naya et al. 2002). In this sense, the Argentine shortfin squid and the anchovy, two of the main prey for fur seals, are known to fluctuate spatio-temporally in the area 
(Brunetti et al. 1998, Hansen 2000). However, South American fur seals might migrate along the southwestern Atlantic Ocean but such migration cannot be traced using nitrogen-15 and carbon-13 stable isotopes due to the relative homogeneity of the isotopic landscape throughout the continental shelf (McMahon et al. 2013). In this regard, mean $( \pm$ SD) stable isotope values of bone samples from subadult and adult male fur seals from northern and central Patagonia $\left(\delta^{15} \mathrm{~N}:+20.6 \% \pm 1.0, \delta^{13} \mathrm{C}:-13.5 \% \pm 0.5\right.$; this study) are almost identical to those of adult male fur seals breeding at Uruguayan colonies $\left(\delta^{15} \mathrm{~N}:+20.6 \%\right.$ $\pm 0.6, \delta^{13} \mathrm{C}:-13.6 \% \pm 0.8$; Vales et al. 2014). The hypothesis of movement of individuals among breeding colonies is supported by evidence of mitochondrial DNA analysis of fur seals from Patagonia, Mar del Plata and Uruguay pointing to a single Atlantic population maintained by an ancient gene flow (Crespo et al. 2015). Therefore, it is possible that resident fur seals from northern and central Patagonia feed throughout the year in the region; whereas fur seals from adjacent colonies (e.g. Uruguay and the Falkland [Malvinas] Islands) exploit the abundant food resources of the region during the non-breeding season (Svendsen et al. 2013). Nevertheless, further research contemplating the use of satellite-tracking devices is needed in order to shed some light on the pelagic dispersion of fur seals at sea.

Finally, the present study reveals a potential overlap in the use of resources between male fur seals from all ages and fisheries in northern and central Patagonia. Prey that constitute the bulk of the diet for fur seals are subjected to intensive (e.g. hake and Argentine shortfin squid), moderate (red shrimp) or almost non-existent (anchovy) fishing activities in the region (Brunetti et al. 1998, Bertuche et al. 2000, Hansen 2000, Bertolotti et al. 2001). It should also be considered that fishing and marine mammal hunting have dramatically modified the structure of marine ecosystems off Patagonia during the last centuries (Saporiti et al. 2014). Squid and anchovy populations may have increased due to 18th-20th century harvest of fur seal and sea lion, and hake depletion during the mid-1990s (Koen Alonso \& Yodzis 2005). In turn, the increased availability of anchovies by predation release may explain the population expansion of the Magellanic penguin Spheniscus magellanicus during the 20th century (Boersma et al. 1990). Hence, the increase in the fur seal and sea lion populations during the last decades in the region, as a result of legal protection (Dans et al. 2004, Crespo et al. 2015), is expected to result in a reduced abundance of squid and anchovy in the ecosystem, which may result in a decrease in food availability for the penguin population and an increased conflict with the fishing industry. Nevertheless, these issues should be addressed in future investigations to assess the relevance of such potential competition for resources and its implications for the conservation status of these species.

Acknowledgements. This research was funded by Fundación BBVA through the project 'Efectos de la explotación humana sobre depredadores apicales y la estructura de la red trófica del Mar Argentino durante los últimos 6.000 años' (BIOCON 08 - 194/09 2009-2011); Agencia Nacional de Promoción Científica y Tecnológica (PICT No. 2110); Mohamed bin Zayed Species Conservation Fund Project No. 0925516; the Zoo d'Amneville, France; and the Society for Marine Mammalogy Small Grants in Aid of Research (20112012). This research article is part of the $\mathrm{PhD}$ thesis of D.G.V. At the time this manuscript was written, D.G.V. was supported by a Fellowship Program from the National Research Council of Argentina (CONICET), and L.Z. was supported by a Fellowship from the National Commission of Scientific and Technological Research of Chile (CONICYT). The authors thank Guillermo Svendsen, Alejandra Romero and ranger Rodrigo Amado for their help in fieldwork, Florencia Grandi for her collaboration as reader in the process of age determination, and Laura Silva, Fabiana Saporiti and Rocío Loizaga de Castro for their assistance with sample processing. Finally, the authors thank the 3 anonymous reviewers for their valuable comments and suggestions that helped greatly to improve the manuscript.

\section{LITERATURE CITED}

Acha EM, Guerrero R, Favero M, Bava J (2004) Marine fronts at the continental shelves of austral South America: physical and ecological processes. J Mar Syst 44: 83-105

Acuña HO, Francis JM (1995) Spring and summer prey of the Juan Fernandez fur seal, Arctocephalus philippii. Can J Zool 73:1444-1452

Aguilar A, Giménez J, Gómez-Campos E, Cardona L, Borrell A (2014) $\delta^{15} \mathrm{~N}$ does not reflect fasting in Mysticetes. PLoS ONE 9:e92288

Arnould JPY (2008) Southern fur seals Arctocephalus spp. In: Perrin WF, Würsig B, Thewissen JGM (eds) Encyclopedia of marine mammals, 2nd edn. Academic Press, San Diego, CA p 1079-1084

Aurioles-Gamboa D, Camacho-Ríos FJ (2007) Diet and feeding overlap of two otariids, Zalophus californianus and Arctocephalus townsendi: implications to survive environmental uncertainty. Aquat Mamm 33:315-326

Batallés LM, Pin O, Lima M (1990) Estudio del crecimiento del lobo fino sudamericano (Arctocephalus australis) en Isla de Lobos, Uruguay. Frente Marit 7:69-73

Baylis AMM, Arnould JPY, Staniland IJ (2014) Diet of South American fur seals at the Falkland Islands. Mar Mamm Sci 30:1210-1219

Bertolotti MI, Verazay GA, Errazti E, Pagani AN, Buono JJ (2001) Flota pesquera Argentina. Evolución durante el periodo 1960-1998, con una actualización al 2000. In: Boschi E (ed) El Mar Argentino y sus Recursos 
Pesqueros, Tomo III: Evolución de la flota pesquera Argentina, artes de pesca y dispositivos selectivos. Publicaciones Especiales Instituto Nacional de Investigación y Desarrollo Pesquero (INIDEP), Mar del Plata, p 9-53

Bertuche D, Fischbach C, Roux A, Fernández M, Piñero R 2000. Langostino (Pleoticus muelleri). In: Bezzi S, Akselman R, Boschi E (eds) Síntesis del estado de las pesquerías marítimas argentinas y de la Cuenca del Plata. Años 1997-1998, con una actualización de 1999. Publicaciones Especiales Instituto Nacional de Investigación y Desarrollo Pesquero (INIDEP), Mar del Plata, p 179-190

Bligh EG, Dyer WJ (1959) A rapid method of total lipid extraction and purification. Can J Biochem Physiol 37: 911-917

Boersma DP, Stokes D, Yorio P (1990) Reproductive variability and historical change of Magellan penguin (Spheniscus magellanicus) at Punta Tombo, Argentina. In: Davis LS, Darby JT (eds) Penguin biology. Academic Press, San Diego, CA, p 15-43

Borella F, Grandi F, Vales DG, Goodall RNP, Crespo EA (2013) Esquema preliminar de fusión epifisaria en huesos de lobos marinos (Arctocephalus australis y Otaria flavescens), su contribución en los análisis zooarqueológicos. In: Zangrando AF, Barberena R, Gil A, Neme G and others (eds) Tendencia teórico-metodológicas y casos de estudios en la arqueología de Patagonia. Editorial Altuna Impresiones, San Rafael, p 39-51

Boschi EE, Fischbach CE, Iorio MI (1992) Catálogo ilustrado de los crustáceos estomatópodos y decápodos marinos de Argentina. Frente Marit 10:7-94

Brunetti NE, Ivanovic ML, Elena B (1998) Calamares omastréfidos (Cephalopoda, Ommastrephidae). In: Boschi E (ed) El Mar Argentino y sus recursos pesqueros, Tomo II: Los moluscos de interés pesquero. Cultivos y estrategias reproductivas de bivalvos y equinoideos. Publicaciones Especiales Instituto Nacional de Investigación y Desarrollo Pesquero (INIDEP), Mar del Plata, p 37-68

$>$ Bunn SE, Loneragan NR, Kempster MA (1995) Effects of acid washing on stable isotope ratios of $\mathrm{C}$ and $\mathrm{N}$ in penaeid shrimp and seagrass: implications for food-web studies using multiple stable isotopes. Limnol Oceanogr 40:622-625

> Calzada N, Lockyer CH, Aguilar A (1994) Age and sex composition of the striped dolphin die-off in the western Mediterranean. Mar Mamm Sci 10:299-310

> Cherel Y, Kernaléguen L, Richard P, Guinet C (2009) Whisker isotopic signature depicts migration patterns and multi-year intra- and inter-individual foraging strategies in fur seals. Biol Lett 5:830-832

> Chouvelon T, Spitz J, Caurant F, Mèndez-Fernandez $\mathrm{P}$ and others (2012) Revisiting the use of $\delta^{15} \mathrm{~N}$ in meso-scale studies of marine food webs by considering spatio-temporal variations in stable isotopic signatures - the case of an open ecosystem: the Bay of Biscay (North-East Atlantic). Prog Oceanogr 101:92-105

> Ciancio JE, Pascual MA, Beauchamp DA (2007) Energy density of Patagonian aquatic organisms and empirical predictions based on water content. Trans Am Fish Soc 136: 1415-1422

Costa DP (1991) Reproductive and foraging energetics of pinnipeds: implications for life history patterns. In: Renouf D (ed) The behaviour of pinnipeds. Chapman \& Hall, London, p 300-344

Costa DP, Kuhn CE, Weise MJ, Shaffer SA, Arnould JPY (2004) When does physiology limit the foraging be- haviour of freely diving mammals? Int Congr Ser 1275: 359-366

Crespo EA, Schiavini ACM, Pérez Macri G, Reyes L, Dans S (1994) Estudios sobre determinación de edad en mamíferos marinos del Atlántico Sudoccidental. In: Oporto JA (ed) Anales IV Reunión de Trabajo de Especialistas en Mamíferos Acuáticos de América del Sur. Centro de Investigaciones y Manejo de Mamíferos Marinos, Valdivia, p 31-55

Crespo EA, García NA, Dans S, Pedraza SN (2008) Mamíferos marinos, Arctocephalus australis. In: Boltovskoy D (ed) Atlas de Sensibilidad Ambiental de la Costa y el Mar Argentino. Secretaría de Ambiente y Desarrollo Sustentable de la Nación (Proyecto ARG 02/018 Conservación de la Diversidad Biológica y Prevención de la Contaminación Marina en Patagonia), Buenos Aires, p 1-9

Crespo EA, Schiavini ACM, García NA, Franco Trecu V and others (2015) Status, population trend and genetic structure of South American fur seals Arctocephalus australis in southwestern Atlantic waters. Mar Mamm Sci, doi: 10.1111/mms.12199

> Dans SL, Crespo EA, Pedraza SN, Koen Alonso M (2004) Recovery of the South American sea lion (Otaria flavescens) population in northern Patagonia. Can J Fish Aquat Sci 61:1681-1690

Dassis M, Farenga M, Bastida R, Rodríguez D (2012) At-sea behavior of South American fur seals: influence of coastal hydrographic conditions and physiological implication. Mamm Biol 77:47-52

DeNiro MJ, Epstein S (1978) Influence of diet on the distribution of carbon isotopes in animals. Geochim Cosmochim Acta 42:495-506

DeNiro MJ, Epstein S (1981) Influence of diet on the distribution of nitrogen isotopes in animals. Geochim Cosmochim Acta 45:341-351

> Drago M, Cardona L, Crespo EA, Aguilar A (2009a) Ontogenic dietary changes in South American sea lions. J Zool 279:251-261

> Drago M, Crespo EA, Aguilar A, Cardona L, García N, Dans SL, Goodall N (2009b) Historic diet change of the South American sea lion in Patagonia as revealed by isotopic analysis. Mar Ecol Prog Ser 384:273-286

Forero MG, Bortolotti GR, Hobson KA, Donazar JA, Bertelotti M, Blanco G (2004) High trophic overlap within the seabird community of Argentinean Patagonia: a multiscale approach. J Anim Ecol 73:789-801

- France RL (1995) Carbon-13 enrichment in benthic compared to planktonic algae: foodweb implications. Mar Ecol Prog Ser 124:307-312

> Franco-Trecu V, Aurioles-Gamboa D, Arim M, Lima M (2012) Prepartum and postpartum trophic segregation between sympatrically breeding female Arctocephalus australis and Otaria flavescens. J Mammal 93:514-521

> Franco-Trecu V, Aurioles-Gamboa D, Inchausti P (2014) Individual trophic specialisation and niche segregation explain the contrasting population trends of two sympatric otariids. Mar Biol 161:609-618

Gentry RL, Kooyman GL, Goebel ME (1986) Feeding and diving behaviour of northern fur seals. In: Gentry RL, Kooyman GL (eds) Fur seals: maternal strategies on land and at sea. Princeton University Press, Princeton, NY, p 61-78

Gerpe MS, Ponce de León A, Bastida R, Moreno VJ, Rodríguez DH (2009) Sharp accumulation of heavy met- 
als after weaning in the South American fur seal Arctocephalus australis. Mar Ecol Prog Ser 375:239-245

Hansen JE (2000) Anchoíta (Engraulis anchoita). In: Bezzi SI, Akselman R, Boschi EE (eds) Síntesis del estado de las pesquerías marítimas argentinas y de la Cuenca del Plata. Años 1997-1998, con la actualización de 1999. Publicaciones Especiales INIDEP, Mar del Plata, p 205-216

Heithaus MR, Dill LM (2008) Feeding strategies and tactics. In: Perrin WF, Würsig B, Thewissen JGM (eds) Encyclopedia of marine mammals, 2nd edn. Academic Press, San Diego, CA, p 414-423

> Hirons AC, Schell DM, Finney BP (2001a) Temporal records of $\delta^{13} \mathrm{C}$ and $\delta^{15} \mathrm{~N}$ in North Pacific pinnipeds: inferences regarding environmental change and diet. Oecologia 129:591-601

> Hirons AC, Schell DM, St. Aubin DJ (2001b) Growth rates of vibrissae of harbor seals (Phoca vitulina) and Steller sea lions (Eumetobias jubatus). Can J Zool 79:1053-1061

Hobson KA (1999) Tracing origins and migration of wildlife using stable isotopes: a review. Oecologia 120:314-326

Hobson KA, Sease JL (1998) Stable isotope analyses of tooth annuli reveal temporal dietary records: an example using Steller sea lions. Mar Mamm Sci 14:116-129

Hobson KA, Wassenaar LI (1999) Stable isotope ecology: an introduction. Oecologia 120:312-313

Hobson KA, Piatt JF, Pitocchelli J (1994) Using stable isotopes to determine seabird trophic relationships. J Anim Ecol 63:786-798

Hobson KA, Schell D, Renouf D, Noseworthy E (1996) Stable carbon and nitrogen isotopic fractionation between diet and tissues of captive seals: implications for dietary reconstructions involving marine mammals. Can J Fish Aquat Sci 53:528-533

Hückstädt LA, Rojas CP, Antezana T (2007) Stable isotope analysis reveals pelagic foraging by the southern sea lion in central Chile. J Exp Mar Biol Ecol 347:123-133

Kernaléguen L, Cazelles B, Arnould JPY, Richard P, Guinet C, Cherel Y (2012) Long-term species, sexual and individual variations in foraging strategies of fur seals revealed by stable isotopes in whiskers. PLoS ONE 7: e32916

Koen Alonso M, Yodzis P (2005) Multispecies modelling of some components of the marine community of northern and central Patagonia, Argentina. Can J Fish Aquat Sci 62:1490-1512

Kooyman GL (1989) Diverse divers: physiology and behaviour. Springer, Berlin

> Lalas C, Webster T (2014) Contrast in the importance of arrow squid as prey of male New Zealand sea lions and New Zealand fur seals at The Snares, subantarctic New Zealand. Mar Biol 161:631-643

> Laptikhovsky V (2009) Oceanographic factors influencing the distribution of South American fur seal, Arctocephalus australis around the Falkland Islands before the breeding season. J Mar Biol Assoc UK 89:1597-1600

> Lee-Thorp JA, Sealy JC, Van Der Merwe NJ (1989) Stable carbon isotope ratio difference between bone collagen and bone apatite, and their relationship to diet. J Archaeol Sci 16:585-599

> Lewis R, O'Connell TC, Lewis M, Campagna C, Hoelzel AR (2006) Sex-specific foraging strategies and resource partitioning in the southern elephant seal (Mirounga leonina). Proc R Soc Lond B Biol Sci 273:2901-2907

> Lorrain A, Savoye N, Chauvaud L, Paulet Y, Naulet N (2003) Decarbonation and preservation method for the analysis of organic $\mathrm{C}$ and $\mathrm{N}$ contents and stable isotope ratios of low-carbonated suspended particulate material. Anal Chim Acta 491:125-133

Lutz VA, Segura V, Dogliotti AI, Gagliardini DA, Bianchi AA, Balestrini CF (2010) Primary production in the Argentine Sea during spring estimated by field and satellite models. J Plankton Res 32:181-195

Majluf P (1989) Reproductive ecology of South American fur seals in Peru. In: Pauly D, Muck P, Mendo J, Tsukayama I (eds) The Peruvian upwelling ecosystem: dynamics and interactions. ICLARM Conf Proc 18. Instituto del Mar del Peru (IMARPE), Callao, p 332-343

Makhado AB, Bester MN, Somhlaba S, Crawford RJM (2013) The diet of the subantarctic fur seal Arctocephalus tropicalis at Marion Island. Polar Biol 36:1609-1617

Martin C, Bentaleb I, Steelandt S, Guinet C (2011) Stable carbon and nitrogen isotope variations in canine dentine growth layers of Kerguelen southern elephant seals. Mar Ecol Prog Ser 439:295-305

> Martínez del Rio C, Wolf N, Carleton SA, Gannes LZ (2009) Isotopic ecology ten years after a call for more laboratory experiments. Biol Rev Camb Philos Soc 84:91-111

> McMahon KW, Hamady LL, Thorrold SR (2013) A review of ecogeochemistry approaches to estimating movements of marine animals. Limnol Oceanogr 58:697-714

Minagawa M, Wada E (1984) Stepwise enrichment of ${ }^{15} \mathrm{~N}$ along food chains: further evidence and the relation between $\delta^{15} \mathrm{~N}$ and animal age. Geochim Cosmochim Acta 48:1135-1140

Molina-Schiller D, Pinedo MC (2004) Growth layer patterns in Arctocephalus australis canine teeth: evaluation of techniques for age determination. Lat Am J Aquat Mamm (LAJAM) 3:107-118

- Naya DE, Arim M, Vargas R (2002) Diet of South American fur seals (Arctocephalus australis) in Isla de Lobos, Uruguay. Mar Mamm Sci 18:734-745

Newsome SD, Koch P, Etnier M, Aurioles-Gamboa D (2006) Using carbon and nitrogen isotope values to investigate maternal strategies in northeast Pacific otariids. Mar Mamm Sci 22:556-572

> Newsome SD, Bentall G, Tinker M, Oftedal O, Ralls K, Fogel M, Estes J (2010a) Variation in diet-vibrissae $\delta^{13} \mathrm{C}$ and $\delta^{15} \mathrm{~N}$ trophic discrimination factors in a wild population of California sea otters (Enhydra lutris nereis). Ecol Appl 20:1744-1752

Newsome SD, Clementz MT, Koch PL (2010b) Using stable isotope biogeochemistry to study marine mammal ecology. Mar Mamm Sci 26:509-572

Oliveira LR, Ott PH, Malbarba LR (2008) Ecologia alimentar dos pinípedes do sul do Brasil e uma avaliação de suas interações com atividades pesqueiras. In: Reis NRd, Peracchi AL, Dos Santos GASD (eds) Ecologia de mamíferos. Technical Books Editora, Londrina, p 97-116

Orr AJ, Newsome SD, Laake JL, VanBlaricom GR, DeLong RL (2011) Ontogenetic dietary information of the California sea lion (Zalophus californianus) assessed using stable isotope analysis. Mar Mamm Sci 28:714-732

> Páez-Rosas D, Aurioles-Gamboa D, Alava JJ, Palacios DM (2012) Stable isotopes indicate differing foraging strategies in two sympatric otariids of the Galapagos Islands. J Exp Mar Biol Ecol 424-425:44-52

Page B, McKenzie J, Goldsworthy SD (2005) Dietary resource partitioning among sympatric New Zealand and Australian fur seals. Mar Ecol Prog Ser 293:283-302

Parnell A, Inger R, Bearhop S, Jackson AL (2008) SIAR: 
Stable Isotope Analysis in R. http://cran.r-project.org/ web/packages/siar/index.html

Phillips DL, Inger R, Bearhop S, Jackson AL and others (2014) Best practices for use of stable isotope mixing models in food-web studies. Can J Zool 92:823-835

Pinedo MC (1986) Mortalidade de Pontoporia blainvillei, Tursiops gephyreus, Otaria flavescens e Arctocephalus australis na costa do Rio Grande do Sul, Brasil, 19761983. In: Castello HP, Wais IR (eds) Actas I Reunión de Trabajo de Especialistas en Mamíferos Acuáticos de América del Sur. Museo Argentino de Ciencias Naturales Bernardino Rivadavia y Grupo Cetáceos de Fundación Vida Silvestre Argentina, Buenos Aires, p 187-199

Pinedo MC (1998) Mamíferos e Tartarugas Marinhos. In: Seeliger U, Odebrecht C, Castello JP (eds) Os Ecossistemas Costeiro e Marinho do Extremo Sul do Brasil. Ecoscientia, Rio Grande, p 166-170

Ponce de León A (1984) Lactancia y composición cuantitativa de la leche del lobo fino sudamericano Arctocephalus australis (Zimmermann, 1783). In: Industria Lobera y Pesquera del Estado. Anales. Artes Gráficas Poligraf, Montevideo, p 43-58

> Post DM (2002) Using stable isotopes to estimate trophic position: models, methods, and assumptions. Ecology 83: 703-718

Reid K, Dexter D, Staniland IJ (2006) Spatial and temporal variability in the fish diet of Antarctic fur seal (Arctocephalus gazella) in the Atlantic sector of the Southern Ocean. Can J Zool 84:1025-1037

Riofrío-Lazo M, Aurioles-Gamboa D (2013) Timing of isotopic integration in marine mammal skull: comparative study between calcified tissues. Rapid Commun Mass Spectrom 27:1076-1082

Rivas AL, Dogliotti AI, Gagliardini DA (2006) Satellitemeasured surface chlorophyll variability in the Patagonian shelf. Cont Shelf Res 26:703-720

Rodríguez L, Bahamonde R (1986) Contribución al conocimiento de Munida subrugosa (White, 1847) en la XII Región, Chile. In: Arana P (ed) La Pesca en Chile. Escuela de Ciencias del Mar PUCV, Valparaíso, p 283-296

Roux A, Piñero R, Moriondo P, Fernández M (2009) Diet of the red shrimp Pleoticus muelleri (Bate, 1888) in Patagonian fishing grounds, Argentine. Rev Biol Mar Oceanogr 44:775-781

Saporiti F, Bearhop S, Silva L, Vales DG and others (2014) Longer and less overlapping food webs in anthropogenically disturbed marine ecosystems: confirmations from the past. PLoS ONE 9:e103132

Scheffer VB (1950) Growth layers in teeth of Pinnipedia as an indication of age. Science 112:309-311

Schiavini ACM, Lima M, Batallés LM (1992) Growth structures of maxillary canines of the southern fur seal (Arctocephalus australis). Mar Mamm Sci 8:89-93

Schoeninger MJ, DeNiro MJ (1984) Nitrogen and carbon isotopic composition of bone collagen from marine and terrestrial animals. Geochim Cosmochim Acta 48: 625-639

Editorial responsibility: Peter Corkeron, Woods Hole, Massachusetts, USA
Seguel M, Pavés H, Paredes E, Schlatter R (2013) Causes of mortality in South American fur seal pups (Arctophoca australis gracilis) at Guafo Island, southern Chile (20042008). Mar Mamm Sci 29:36-47

> Stegall VK, Farley SD, Rea LD, Pitcher KW and others (2008) Discrimination of carbon and nitrogen isotopes from milk to serum and vibrissae in Alaska Steller sea lions (Eumetopias jubatus). Can J Zool 86:17-23

Stewardson CL (2001) Biology and conservation of Cape (South African) fur seal Arctocephalus pusillus pusillus (Pinnipedia: Otariidae) from the Eastern Cape coast of South Africa. PhD dissertation, The Australian National University, Canberra

Strange IJ (1983) The Falkland Islands, 3rd edn. David and Charles, London

Strange IJ (1992) A field guide to the wildlife of the Falkland Islands and South Georgia. Harper and Collins, London

Svendsen GM, Dans SL, González RA, Romero MA, Crespo EA (2013) Occurrence of South American fur seals Arctocephalus australis (Zimmermann, 1783) in San Matías Gulf, Patagonia, Argentina. Lat Am J Aquat Res 41: 576-583

> Thompson D, Moss SEW, Lovell P (2003) Foraging behaviour of South American fur seals Arctocephalus australis: extracting fine scale foraging behaviour from satellite tracks. Mar Ecol Prog Ser 260:285-296

> Vales DG, Saporiti F, Cardona L, Oliveira LR and others (2014) Intensive fishing has not forced dietary change in the South American fur seal Arctophoca (= Arctocephalus) australis off Río de la Plata and adjoining areas. Aquat Conserv Mar Freshw Ecosyst 24:745-759

Vallejos A (2010) Dieta del lobo fino austral, Arctocephalus australis (Zimmermann, 1783), en Isla Guafo. Degree dissertation, Departamento de Acuicultura y Recursos Acuáticos, Universidad de los Lagos, Osorno

Vaz-Ferreira R (1982) Arctocephalus australis, South American fur seal. FAO Fish Ser 5:497-508

Vaz-Ferreira R, Ponce de León A (1984) Estudios sobre Arctocephalus australis (Zimmermann, 1783), lobo de dos pelos sudamericano, en el Uruguay. Contrib Dep Oceanogr (F.H.C.) Montevideo 1:1-18

Vaz-Ferreira R, Ponce de León A (1987) South American fur seal, Arctocephalus australis, in Uruguay. In: Croxall JP, Gentry RL (eds) Status, biology and ecology of fur seals. NOAA Technical Report 51, p 29-32

- Vinuesa JH (2005) Distribución de crustáceos decápodos y estomatópodos del Golfo San Jorge, Argentina. Rev Biol Mar Oceanogr 40:7-21

Vinuesa JH, Varisco M (2007) Trophic ecology of the lobster krill Munida gregaria in San Jorge Gulf, Argentina. Invest Mar Univ Catol Valparaiso 35:25-34

Walters A, Lea MA, van den Hoff J, Field IC and others (2014) Spatially explicit estimates of prey consumption reveal a new krill predator in the Southern Ocean. PLoS ONE 9:e86452

Weise MJ, Harvey JT, Costa DP (2010) The role of body size in individual-based foraging strategies of a top marine predator. Ecology 91:1004-1015

Submitted: August 1, 2014; Accepted: January 21, 2015

Proofs received from author(s): March 13, 2015 